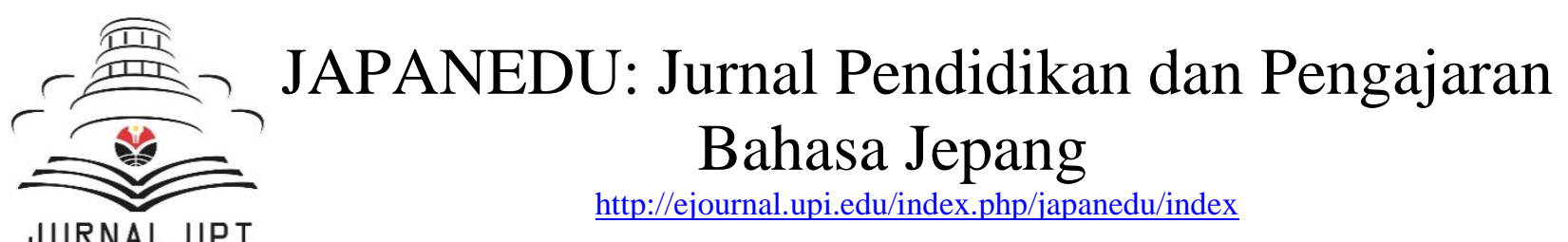

\title{
Politeness of Women's Language (Joseigo) by Shin Tanokura in Drama Series of Oshin
}

\author{
Eko Kurniawan \\ Program Studi Sastra Jepang, Universitas Jenderal Soedirman, Purwokerto - Indonesia \\ eko.kurniawan@unsoed.ac.jp
}

\begin{abstract}
A B S T R A C T
This study aims to assess information about variety of women's language by Shin Tanokura, women's language that represent the principles of politeness and politeness scale in drama series of Oshin. Research based on theory of Kindaichi (1988) for variety of women's language and theory of Leech (2011) for the principles of politeness and politeness scale. This is kind of qualitative research. The method used in this research is the descriptive analysis. Source of data in this study is drama series of Oshin. While the data in this study are uttarances containing women's language, women's language that represent the principles of politeness and politeness scale. Data collection technique which used is observing method.The results showed, variety of women's language by Shin Tanokura in drama series of Oshin is based on the theory of Kindaichi (1988): 1) Goi level, consists of using shuujoshi (wa, kashira, mono dan no), kantanshi (maa dan ara), ninshoudaimeishi (atakushi, atashi dan anata), koshou ( san, sama dan anata), keigo (teineigo, kenjougo dan sonkeigo) dan wago (tsuite iku); 2) Tougo level, consists of using iikirenai hyougen dan kurikaeshi hyougen; 3) Danwa level, consists of using youkyuu hyougen, aizuchi dan aisatsu, kimari monku. The classifications above represented in six maxims of the principles of politeness, tact maxim, generosity maxim, approbation maxim, modesty maxim, agreement maxim and sympathy maxim. According on theory of Leech (2011), there are three politeness scales, 1) Profit and loss scale, 2) Indirect scale and 3) Which like scale. Then, three scale are linked to one another and implemented in women's language by Shin Tanokura in drama series of Oshin, the result are profit on addressees-direct-high, profit on addressees-directmedium, profit on addressees-direct-low, profit on addressees-indirect-medium, profit on addressees-indirect-low, profit on speaker, addressees-direct-low and profit on speaker, addressees-indirect-high.
\end{abstract}

\section{K E Y W O R D S}

Women's language; Principles of politeness; Politeness scale

A R T I C L E IN F O

First received: 17 May $2018 \quad$ Final proof accepted: 23 May 2018

Available online: 01 June 2018

\section{PENDAHULUAN}

Bahasa Jepang merupakan salah satu bahasa yang memiliki variasi bahasa yang beragam. Salah satu contoh variasi bahasa dalam bahasa Jepang ditinjau dari jenis kelamin penuturnya yaitu variasi bahasa wanita (joseigo atau onna kotoba). Joseigo atau 
onna kotoba adalah variasi bahasa dalam bahasa Jepang yang hanya digunakan oleh penutur wanita. Variasi bahasa wanita juga sering dijumpai penggunaannya dalam majalah-majalah, novel-novel, buku-buku komik, siaran-siaran radio atau televisi seperti pada acara film dan drama. Salah satu contoh drama serial yang banyak dijumpai penggunaan variasi bahasa wanita dalam dialog-dialognya adalah drama serial Oshin. Berikut contoh penggunaan variasi bahasa wanita dalam drama serial Oshin:

(1) Oshin :

Ohayougozaimasu. Kyou kara, oku no mo

koto wa souji mo sentaku mo daidokoro shigoto

minna, watakushi ga itashimasu.

'Selamat pagi. Dari sekarang, akan melakukan semua pekerjaan rumah tangga seperti bersih-bersih, mencuci, pekerjaan dapur dan lain sebagainya'.

Genemon :

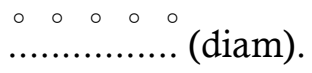

(O80/01.22-01.30)

Dari contoh percakapan di atas, penggunaan variasi bahasa wanita dapat dilihat dari segi bentuk dan pilihan katanya. Dari segi bentuk yaitu ditandai dengan penggunaan verba itashimasu 'melakukan'. Dari segi pilihan katanya ditandai dengan penggunaan kata ganti orang pertama yaitu atakushi saya'. Kata atakushi merupakan kata ganti orang pertama tunggal yang termasuk dalam kata ganti orang yang santun. Begitu pula verba itashimasu merupakan verba khusus yang termasuk dalam bahasa santun atau keigo dalam jenis kenjougo. Penggunaan kata ganti orang atakushi dan verba itashimasu oleh tokoh Oshin merupakan representasi variasi bahasa wanita yang bertujuan untuk menghormati petuturnya. Walaupun verba itashimasu dapat juga digunakan oleh pria namun verba itashimasu yang termasuk dalam bahasa santun dirasa janggal apabila diucapakan oleh penutur wanita kepada pembantunya. Verba itashimasu merupakan verba bentuk formal dan bentuk santun yang digunakan saat situasi resmi dan jarang sekali digunakan oleh pria dalam situasi non formal maupun dalam lingkungan keluarga atau kerabat dekat.

Dari tuturan tokoh Oshin (1) di atas juga dapat dilihat bahwa tokoh Oshin yang merupakan orang yang baru masuk dalam lingkungan keluarga Tanokura berupaya untuk menghormati saudara Genemon (petutur) yang merupakan pembantu rumah tangga. Padahal biasanya orang Jepang menggunakan bahasa non formal kepada petutur yang mempunyai hubungan kekerabatan lebih dekat apalagi dengan petutur yang merupakan anggota keluarga dan orang yang tinggal dalam satu lingkungan atau rumah. Selain itu, jika dilihat dari prinsip kesantunan tindakan yang dilakukan Oshin mematuhi maksim kebijaksanaan dan maksim kedermawanan yaitu ketika Oshin berusaha mengurangi keuntungan bagi dirinya sendiri dan memaksimalkan keuntungan kepada petutur. Hal itu dilakukan 
dengan cara menawarkan bantuan untuk melakukan semua pekerjaan rumah tangga. Dari uraian di atas, dapat dilihat bahwa tuturan tokoh Oshin dapat mempresentasikan tokoh Oshin sebagai wanita yang menggunakan variasi bahasa wanita atau joseigo dengan menunjukkan kesantunannya dalam berbahasa.

Penelitian terdahulu yang relevan dengan penelitian ini adalah penelitian karya Mineko Masamune tahun 1998 dengan judul Nihongo ni okeru joseigo-danseigo dalam Jurnal Kitariku Daigaku volume 22 halaman 157-163. Dalam penelitian tersebut dibahas tentang penanda kebahasaan dalam bahasa wanita dan bahasa pria. Penelitian selanjutnya yang relevan dengan penelitian ini adalah penelitian karya Junko Nakamura tahun 2000 dalam jurnal Shinshuu Daigaku Ryungakusei Sentaa Kiyou edisi pertama dengan judul Shuujoshi ni okeru danseigo to joseigo. Dalam penelitian tersebut diteliti tentang penggunaan shuujoshi 'partikel akhir' pada suatu kalimat yang digunakan pada bentuk dasar dan bentuk desu-masu. Penelitian ketiga yang relevan dengan penelitian ini adalah penelitian karya Wiwik Setyorini (Tesis, 2007) di Program Studi Pendidikan Bahasa dan Sastra, Program Pasca Sarjana Unesa dengan judul "Tinjauan Penggunaan Shuujoshi sebagai Ragam Bahasa Jender dalam Kelas Bahasa Jepang di Perguruan Tinggi Jawa Timur". Pada penelitian tersebut dibahas penggunaan shuujoshi oleh penutur asli pria dan penutur asli wanita dalam kelas bahasa Jepang di Perguruan Tinggi Jawa Timur serta performansi mahasiswa dan penyebab terjadinya penyimpangan terhadap penggunaan shuujoshi gender.

Relevansi penelitian pertama hingga penelitian ketiga dengan penelitian ini adalah kesamaan tema penelitian, penelitian membahas tentang penggunaan variasi bahasa wanita bahasa Jepang. Pada penelitian kedua dan ketiga membahas penggunaan variasi bahasa wanita bahasa Jepang dilihat dari shuujoshi jender saja. Namun, penelitian ini lebih memiliki kesamaan dengan penelitian pertama yaitu membahas penggunaan variasi bahasa wanita tidak berdasarkan shuujoshi jender saja. Shuujoshi jender hanya merupakan salah satu penanda variasi bahasa wanita. Penelitian "Kesantunan Tuturan Variasi Bahasa Wanita (Joseigo) Tokoh Shin Tanokura dalam drama serial Oshin" mengkaji variasi bahasa wanita tidak hanya berdasarkan shuujoshi jender saja melainkan juga berdasarkan pada aspek-aspek lainnya seperti aspek bentuk, penggunaan kosakata meliputi penggunaan pronomina atau kata ganti orang, penggunaan bahasa sopan dan lain sebagainya. Selain itu, perbedaan penelitian ini dengan ketiga penelitia tersebut di atas yaitu dalam penelitian ini dibahas kesantunan tuturan 
variasi bahasa wanita berdasarkan maksimmaksim dalam prinsip kesantunan.

Kindaichi (1988: 558 - 560) dalam Nihongo Hyakka Daijiten menjelaskan variasi bahasa wanita merupakan ungkapan atau ekspresi kebahasaan yang hanya digunakan oleh wanita sebagai pemiliknya dan dalam bahasa lisan dapat dilihat dari: 1)Bunyi (Oto), yaitu meliputi intonasi (Intoneesion) dan pelesapan fonem (On'in); 2)Bentuk (Keitai), yaitu meliputi partikel akhir (Shuujoshi) dan bahasa santun (keigo); 3)Kosakata (Goi), yaitu meliputi kata ganti orang (ninshoudaimeishi), panggilan (koshou), kata seruan (kantanshi), adjectiva (keiyoushi), adverbia (fukushi), penggunaan Kango (kangoshiyou), kosakata repetoir (goi no Repaatorii) dan bahasa vulgar dan bahasa slang (zokugo, higo); 4)Kalimat (Tougo), yaitu meliputi iikiranai hyougen, kurikaeshi hyougen dan touchikoubun; 5)Wacana (Danwa), yaitu meliputi ungkapan permintaan (youkyuu hyougen), ungkapan persetujuan (aizuchi), salam-kebiasaan (aisatsu, kimari monku) dan candaan-pendapat (joudan, giron). Leech memberikan 6 maksim dalam prinsip kesopanan, yaitu maksim kebijaksanaan (tact maxim), maksim kedermawanan (generosity maxim), maksim pujian (approbation maxim), maksim kerendahhatian (modesty maxim), maksim kesepakatan (agreement maxim), dan maksim kesimpatian (sympathy maxim). Ada tiga skala kesantunan dalam model kesantunan Leech
(1993: 166), yaitu (1) Skala untung rugi, (2) Skala ketidaklangsungan dan (3) Skala kemanasukaan.

\section{METODE}

Penelitian ini menggunakan pendekatan kualitatif karena data yang digunakan dalam penelitian ini tidak menggunakan angkaangka atau variabel-variabel yang harus dibuktikan terlebih dahulu dengan pengujian hipotesis melainkan berupa data deskriptif. Dalam penelitian ini akan dijelaskan dan dijabarkan mengenai penggunaan ragam bahasa wanita (bisa berupa kata, frasa maupun kalimat) tokoh Shin Tanokura dalam drama serial Oshin. Adapun jenis penelitian yang digunakan dalam penelitian ini adalah penelitian deskriptif. Penelitian ini merupakan penelitian deskriptif yang menjabarkan atau memberikan uraian terhadap hasil analisis penggunaan variasi bahasa wanita oleh tokoh Shin Tanokura dalam drama serial Oshin berupa gambaran bahasa sebagaimana adanya secara jelas sesuai dengan tujuan penelitian. Sumber data penelitian ini adalah drama serial Oshin karya Sugako Hashida episode 80 sampai episode 111. Data dalam penelitian ini berupa kalimat-kalimat bahasa Jepang yang menggunakan variasi bahasa wanita yang dituturkan oleh tokoh Shin Tanokura dalam drama serial Oshin episode 80 sampai episode 111. 
Metode pengumpulan data yang digunakan dalam penelitian ini adalah teknik Simak Bebas Libat Cakap (SBLC) dan teknik catat. Dalam hal ini, teknik Simak Bebas Libat Cakap (SBLC) digunakan peneliti untuk menyimak drama serial Oshin sebagai sumber data. Setelah itu, peneliti menggunakan teknik catat untuk mencatat informasi dan data berupa kalimat-kalimat bahasa Jepang yang menggunakan variasi bahasa wanita oleh tokoh Shin Tanokura dalam drama serial Oshin. Setelah melakukan pengumpulan data, seluruh data yang terkumpul kemudian diolah oleh peneliti. Data dianalisis dengan menggunakan metode deskriptif kualitatif yaitu dengan mendeskripsikan secara menyeluruh data yang didapat selama proses penelitian. Pengolahan data kualitatif sejalan dengan pemikiran Miles dan Huberman (2009: 16-18), dilakukan melalui tahap pereduksian, penyajian data, dan penyimpulan. Selanjutnya, data dianalisis mengggunakan metode padan. Metode padan merupakan metode yang dalam praktik analisis data dilakukan dengan menghubungbandingkan antar unsur. Dalam penelitian ini digunakan teknik hubung banding menyamakan (HBS) dan teknik hubung banding membedakan (HBB). Teknik hubung banding menyamakan (HBS) digunakan dalam proses penganalisisan data untuk menyamakan antarunsur, baik unsur intralingual maupun unsur ekstralingual antara tuturan satu dengan tuturan lainnya. Selanjutnya, digunakan teknik hubung banding membedakan (HBB) untuk membedakan antarunsur antara tuturan satu dengan tuturan lainnya. Hal itu dilakukan untuk dapat lebih memperjelas hasil analisis terhadap tuturan yang sama dan tuturan yang berbeda.

Pengujian keabsahan data dalam penelitian ini dilakukan dengan menggunakan teknik triangulasi. Teknik triangulasi digunakan untuk keperluan pengecekan kembali derajat kepercayaan data. Sugiyono (2012: 372 - 373), triangulasi digunakan untuk menguji kredibilitas data dengan cara mengecek data yang telah diperoleh melalui beberapa sumber dengan berbagai cara dan berbagai waktu. Triangulasi yang dilakukan dalam penelitian ini adalah triangulasi data tertulis. Triangulasi tersebut dilakukan dengan cara memastikan ke penutur asli bahasa Jepang yang bernama Ms. Takasaki Michiyo.

\section{HASIL DAN PEMBAHASAN}

\section{Bentuk Tuturan Variasi Bahasa Wanita}

Bentuk tuturan variasi bahasa wanita tokoh Shin Tanokura dalam drama serial Oshin ini difokuskan pada pembahasan yang meliputi 1) Tataran goi, 2) Tataran tougo, dan 3) Tataran danwa. 


\section{Tataran Goi}

Variasi bahasa wanita dalam tataran goi dapat ditunjukkan melaui penggunaan (a) Shuujoshi, (b) Kantanshi, (c) Ninshoudaimeishi, (d) Koshou, (e) Keigo dan (f) Wago.

\section{a. Shuujoshi}

Nomura dan Koike (1978: 123) menjelaskan shuujoshi adalah partikel yang menunjukkan larangan, pertanyaan, kekaguman, menguatkan, penonjolan dan lain-lain yang diletakkan di akhir kalimat.

\section{1) Shuujoshiwa}

Dalam tuturan variasi bahasa wanita (Joseigo) tokoh Shin Tanokura dalam drama serial Oshin penggunaan shuujoshi wa menyatakan rasa kagum.

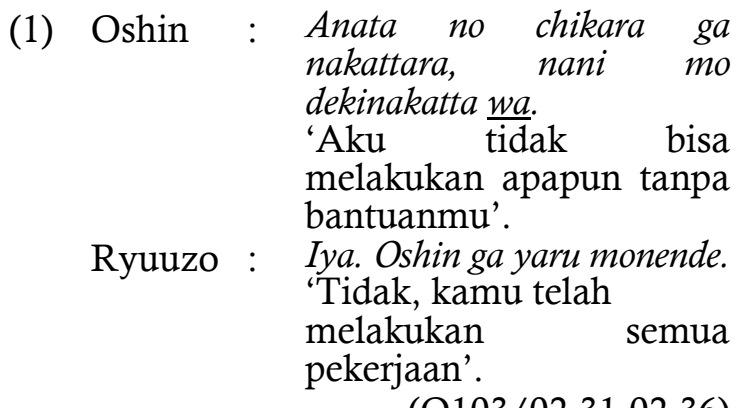
(O103/02.31-02.36)

2) Shuujoshi kashira

Dalam tuturan variasi bahasa wanita (Joseigo) tokoh Shin Tanokura dalam drama serial Oshin penggunaan shuujoshi kashira menyatakan permohonan secara tidak langsung.
(3) Oshin :
Sono koto mo goryoushou shite itadaita ue de?

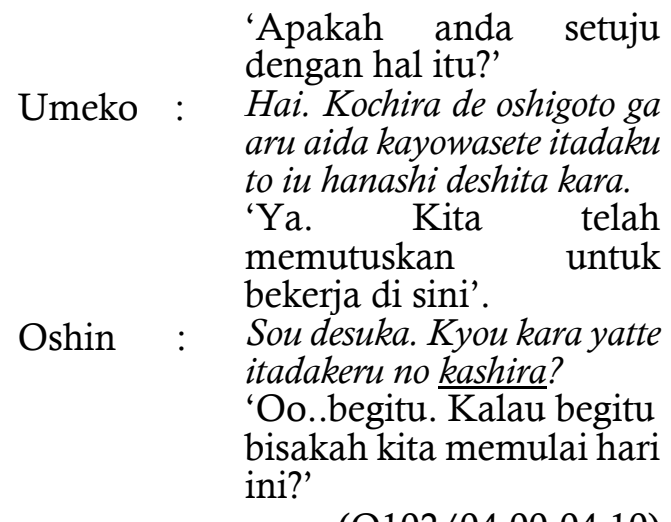

(O102/04.00-04.10)

\section{3) Shuujoshi mono}

Tuturan Oshin pada data (7) di bawah juga merupakan tuturan variasi bahasa wanita. Oshin mengucapkan tuturan bahasa wanita dengan penanda shuujoshi mono kepada saudari Kayo. Namun, shuujoshi mono pada tuturan Oshin data (7) di bawah mengalami penyingkatan dan menjadi mon yang digunakan penutur untuk mengungkapkan suatu pernyataan yang menyatakan alasan.

(7)

$\begin{array}{cl}\text { Oshin : } & \text { Iro-iro tsurai koto mo atta kedo, } \\ & \text { ima wa nan toka jibun de } \\ & \text { erannda michi dakara, jibun de } \\ & \text { mamotte yori hoka nain da } \\ & \text { mon. } \\ & \text { 'Ada beberapa hal yang sulit, } \\ & \text { namun tidak ada jalan lain } \\ & \text { kecuali harus kita jaga } \\ & \text { sendiri karena merupakan } \\ & \text { jalan yang } \\ & \text { telah kita pilih sendiri } \\ & \text { sebelumnya'. } \\ \text { Knda. } & \text { 'Begitulah'. }\end{array}$

(O111/09.57-10.09)

4) Shuujoshi no

Tuturan variasi bahasa wanita dengan penanda shuujoshi no memberikan kesan lembut pada kalimat berita. 
(9) Ryuuzo : Iya-iya, Oshin ga isshoukenmei

Tanokura no ningen ni narou toshite doryoku shiten no mitara, watashi date shiran kao wa dekin kara.

'Oshin, kamu lah yang telah berjuang keras untuk menjadi seorang Tanokura, Aku hanya tak bisa menolaknya'.

Oshin : Kuchi de wa hantai shite iru you na koto itte mone, de wa chanto tasukete kureru no.

'Dia selalu bicara sebaliknya. Padahal berkat dia aku tertolong'.

(O103/02.19-02.30)

\section{b. Kantanshi}

Kata seruan dalam bahasa Jepang disebut kantanshi dan ada pula yang menyebutnya sebagai kandoushi. Penanda tuturan variasi bahasa wanita kantanshi atau kata seruan ara untuk menyatakan keheranan yang kuat.

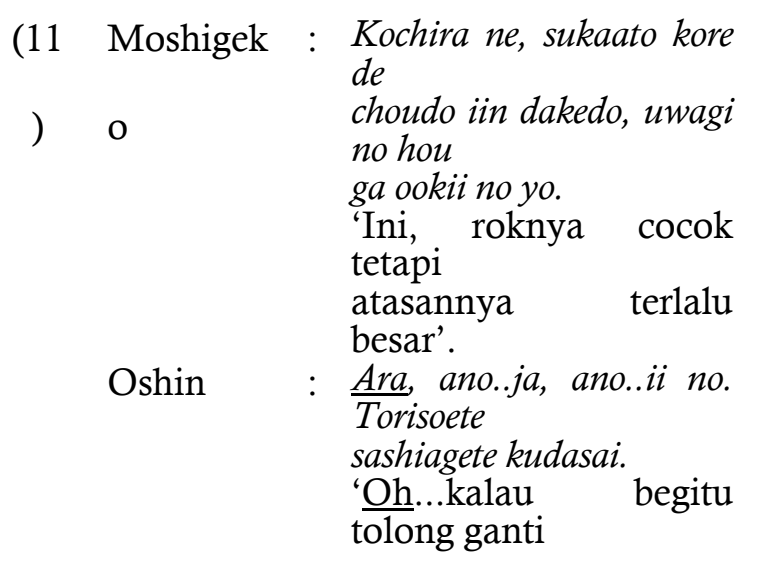

dengan yang baru'.

(O103/04.00-04.10)

\section{c. Ninshoudaimeishi}

Ninshoudaimeishi adalah nama lain dari kata ganti orang dalam bahasa Jepang. Dalam bahasa Jepang terdapat ninshoudaimeishi yang khusus digunakan oleh wanita salah satunya yaitu atakushi.

(12) Oshin

: Ohayougozaimasu. Kyou kara, oku no koto wa souji mo Sentaku mo daidokoro shigoto mo minna, atakushi ga itashimasu.

'Selamat pagi. Dari sekarang, saya akan melakukan semua pekerjaan rumah tangga seperti bersihbersih, mencuci, pekerjaan dapur dan lain sebagainya'.

Genemon : ०० ० 。 (diam).

(O80/01.22-01.30)

\section{d. Koshou}

Koshou adalah panggilan atau sapaan dalam bahasa Jepang yang disematkan setelah nama seseorang.

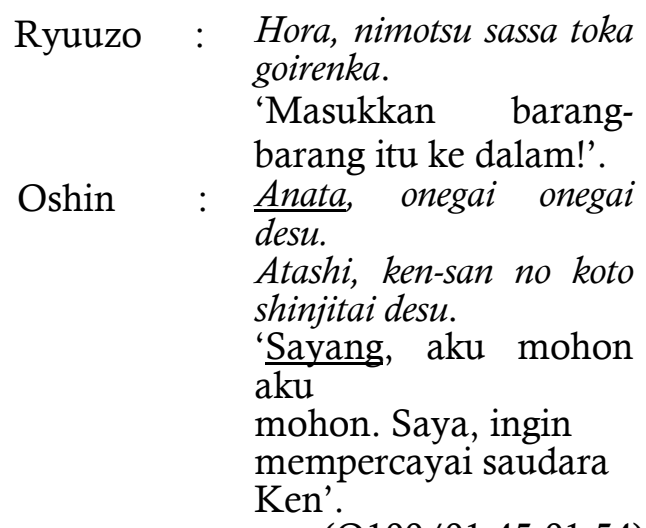
(O100/01.45-01.54)

Tuturan Oshin pada data (17) juga terlihat penggunaan tuturan variasi bahasa wanita. Pada tuturan data di atas, tuturan variasi bahasa wanita ditunjukkan dengan 
penggunaan koshou atau kata sapaan. Kata sapaan yang digunakan Oshin adalah kata anata. Pada tuturan data di atas, kata anata diucapkan Oshin untuk menyapa suaminya, Ryuuzo (petutur). Kata anata merupakan kata sapaan yang sering digunakan wanita untuk menyapa suaminya dengan tujuan menyatakan perasaan sayang.

\section{e. Keigo}

Keigo adalah bahasa santun. Secara umum keigo dibagi menjadi tiga yaitu teineigo, kenjougo dan sonkeigo. Dalam penelitian ini ditemukan tuturan variasi bahasa wanita menggunakan teineigo meliputi penggunaan $\sim g o$ dan $\sim o$.

(18) Oshin

$\begin{array}{ll}\text { Oshin } & \text { Kyou chichi no koto } \\ & \text { wawanakute, Kono aida } \\ & \text { shuugen ageta mon } \\ & \text { dakara. Sono Go-aisatsu } \\ & \text { ukagaimashita. } \\ & \text { 'Kedatangan saya hari } \\ & \text { ini bukan mengenai } \\ & \text { ayah saya melainkan } \\ & \text { untuk } \\ & \text { mengabarkan bahwa } \\ & \text { saya telah menikah. } \\ & \text { Untuk itulah saya } \\ & \text { datang } \\ & \text { mengucapkan salam'. } \\ \text { Onna no : } & \text { Hee, shuugentte? } \\ \text { hito } & \text { 'Hee...menikah?'. }\end{array}$

(O85/04.25-04.38)

(19) Oshin : Otsukaikata wa muzukashiin deshouka. 'Apakah cara

penggunaanya susah? hito okusama mo otsukai ni narun desuka.

'Tidak, siapa pun langsung..apakahnyon ya juga akan

menggunakannya?'

Oshin : Ee.Mishin o oboetarane.

Atashi demo te gurai dekiru janaika to omotte.

'Ya. Jika saya bisa menggunakannya, saya bisamelakukan suatu pekerjaan dengan baik'.

(O101/00.29-00.44)

\section{f. Wago}

(22 Oshin

Atashi mo tsuite ikimasu. Tanokura shoukai mata mukashii no you ni.

'Saya pun akan mengikutimu sampai TokoTanokura seperti dulu'.

Ryuuzo : (Diam)

(O96/11.50-11.55)

Tuturan Oshin pada data (22) di atas, Oshin mengucapkan atashi mo tsuite ikimasu 'akan mengikuti' pada Ryuuzo. Dalam tuturan itu digunakan verba tsuite ikimasu yang merupakan penanda tuturan variasi bahasa wanita. Verba tsuite ikimasu adalah verba bentuk formal dari verba tsuite $i k u$ dan tergolong dalam verba majemuk karena terbentuk dari dua verba. Verba tsuite iku terbentuk dari verba tsuku 'menambah' dan verba $i k u$ 'pergi'. Verba pertama yaitu tsuku diubah menjadi verba bentuk te yaitu tsuite agar bisa digabungkan dengan verba kedua yaitu $i k u$ sehingga membentuk verba baru yaitu tsuite iku yang berarti 'mengikuti'. Berdasarkan asal mula terbentuknya kosakata, 
verba tsuite iku digolongkan dalam wago. Wago adalah kosakata yang berasal dari bahasa Jepang Asli.

\section{Tataran Tougo}

Dalam tataran tougo terdapat beberapa variabel, meliputi (a) Iikiranai hyougen dan (b) Kurikaeshi hyougen.

\section{a. Iikiranai Hyougen}

Iikirenai hyougen merupakan ungkapan atau cara berbicara yang tidak sampai selesai dan biasanya digunakan oleh wanita.

$$
\begin{aligned}
& \text { Oshin : Kawari ni atashi ga } \\
& \text { yattoku } \\
& \text { kara. Hidoku demo } \\
& \text { nattara.. } \\
& \text { 'Sebagai gantinya saya } \\
& \text { yang akan } \\
& \text { melakukannya. } \\
& \text { Kalau menjadi } \\
& \text { semakin parah...'. } \\
& \text { Toshik : Okusan ni, sonna.. } \\
& \text { 'Nyonya, begitu...' } \\
& \text { (O108/02.52- }
\end{aligned}
$$$$
\text { o }
$$

Pada data (23) di atas, Oshin mengucapkan tuturan variasi bahasa wanita kepada Toshiko. Tuturan variasi bahasa wanita tampak pada penggunaan iikirenai hyougen. Hal tersebut dilakukan untuk menutupi maksud penutur yang sesungguhnya agar tidak tampak vulgar dan memberikan kesan santun kepada petutur. Tuturan Oshin menjadi kurang santun dan dirasa terlalu memikirkan diri sendiri jika Oshin menyelesaikan tuturannya misalnya, hidoku demo nattara, ashita hatarakenai kashira

'jika semakin parah mungkin besok tidak akan bisa bekerja'.

\section{b. Kurikaeshi Hyougen}

Kurikaeshi hyougen adalah ungkapan atau ekspresi yang digunakan untuk menyatakan perasaan dengan cara melakukan pengulangan pada kata-kata tertentu dalam sebuah kalimat.

\section{Oshin}

Roku
Rokus-an ni mo, Sabu-san ni mo yoku shite moratte, arigatou hontou ni arigatou. 'Saudara Roku dan Sabu telah banyak membantu, terima kasih, terima kasih banyak'.

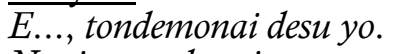

Nani mo yaku ni mo tatanai no ni, nakabu na shuugi made itadakimashite hontou ni arigatou gozaimashita. 'Eh...bukan apa-apa dan terima kasih banyak atas uang tipnya'.

(O100/09.37-09.50)

\section{Tataran Danwa}

Selain pada tataran goi dan tougo, penelitian ini juga memperhatikan bagaimana tataran tougo dalam tuturan variasi bahasa wanita yaitu meliputi (a) Youkyuu hyougen, (b) Aizuchi, dan (c) Aisatsu dan Kimari monku.

\section{a. Youkyuu Hyougen}


Youkyuu hyougen adalah sebuah ungkapan yang digunakan seseorang untuk meminta sesuatu kepada orang lain.

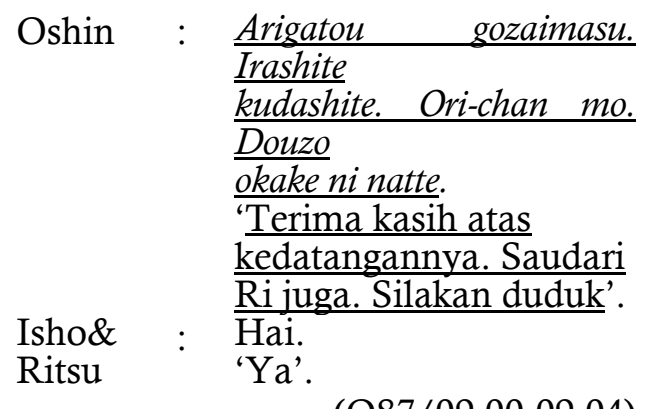

(O87/09.00-09.04)

Tuturan Oshin pada data (26) di atas juga tampak tuturan variasi bahasa wanita yang ditandai dengan penggunaan youkyuu hyougen yaitu ungkapan yang menyatakan permintaan dan penawaran. Oshin mengucapkan tuturan douzo okake ni natte setelah tuturan arigatou gozaimasu. irashite kudashite 'terima kasih atas kedatangannya. Tuturan itu diucapkan Oshin untuk mempersilakan saudara Isho dan Ritsu duduk. Tuturan douzo okake ni natte merupakan tuturan yang menyatakan permintaan atau permohonan secara sopan. Tuturan itu mengalami penyingkatan dari bentuk semestinya yaitu douzo okake ni natte kudasai dengan menghilangkan kata kudasai pada akhir kalimat.

\section{b. Aizuchi}

Aizuchi adalah ekspresi atau ungkapan yang menunjukkan dukungan atau persetujuan terhadap pernyataan petutur.
(29) Ritsu : Isho-san taishitamon desune, yappari.
'Saudari Isho

Melakukannya dengan baik kan ya'.

Oshin : $\quad$ Sorya sou yo.

'Begitulah'.

(O92/11.17-11.20)

Pada data (29) di atas, Oshin (penutur) mengucapkan sorya sou yo kepada Ryuuzo (petutur). Tuturan sou yo merupakan salah satu bentuk dari aizuchi yaitu tuturan yang digunakan untuk mengiyakan ucapan petutur. Oshin menggunakan tuturan itu untuk mengiyakan pernyataan saudari Ritsu yang mengatakan bahwa saudari Isho telah bekerja dengan baik. Tuturan sou yo sudah mengalami penyingkatan dari bentuk formal sou desu yo maupun bentuk non formal sou da yo yaitu dengan membuang kata desu atau da sehingga menjadi sou yo.

\section{c. Aisatsu dan Kimari Monku}

Aisatsu adalah salam dan Kimari Monku adalah kebiasaan atau perkataan yang lazim diucapkan dalam kehidupan sehari-hari. Wanita lebih bersikap patuh dan peduli terhadap adat istiadat sehingga lebih sering mengucapakan aisatsu dan menggunakan kimari monku.

(30) Oshin : Tadaima kaerimashita. Sousou no asagaeri de, moushi wake arimasen. Akemashite omedetou gozaimasu. 'Saya pulang. Maaf saya pulang terlambat. Selamat Tahun Baru'.

Ryuuzo : $\quad \frac{\text { (mengangguk). }}{\text { (menan }}$ 
Oshin : Genji, akemashite omedetou gozaimasu. Kotoshi mo yoroshiku onegaiitashimasu.

"Genji, selamat tahun baru. Tahun ini juga mohon bantuannya'.

(090/00.48-01.07)

\section{Prinsip Kesantunan dalam Tuturan Variasi Bahasa Wanita}

Dalam tuturan variasi bahasa wanita Tokoh Shin Tanokura dalam drama serial Oshin telah ditemukan pematuhan prinsip kesantunan yaitu meliputi pemenuhan 1)Maksim kebijaksanaan, 2)Maksim kedermawanan, 3)Maksim pujian, 4)Maksim kerendahan hati, 5)Maksim kesepakatan dan 6)Maksim kesimpatian.

\section{Maksim Kebijaksanaan}

\begin{tabular}{|c|c|}
\hline Oshin & Dou nasattan desuka \\
\hline & $\frac{\text { sono }}{\text { tokore de? Kochira de }}$ \\
\hline & Dana-sama to issho ni \\
\hline & youi shite arimasu kara. \\
\hline & "Mengapa anda \\
\hline & duduk di \\
\hline & sana? Duduklah di \\
\hline & $\underline{\text { sini }}$ \\
\hline & bersama tuan, saya \\
\hline & $\begin{array}{l}\text { sudah menyiapkan } \\
\text { mejanya'. }\end{array}$ \\
\hline Genemon & $\begin{array}{l}\text { Iie, waza shiyounin } \\
\text { desu. }\end{array}$ \\
\hline & $\begin{array}{l}\text { 'Tidak, saya hanya } \\
\text { seorang pelayan'. }\end{array}$ \\
\hline
\end{tabular}

(O80/03.46-

Tuturan pada data (32) telah memenuhi prinsip kesantunan yaitu maksim kebijaksanaan. Tuturan yang diucapkan Oshin dirasa telah mengurangi kerugian pihak lain yaitu Genemon. Dengan kata lain, Oshin memberikan keuntungan kepada Genemon. Oshin mempersilakan kepada Genemon untuk duduk bersama Ryuuzo di meja yang telah disiapkannya. Pernyataan Oshin itu merupakan bukti pematuhan maksim kebijaksanaan sehingga tuturan yang diucapkan oleh Oshin dikatakan sebagai tuturan yang santun.

\section{Maksim Kedermawanan}

(34) Oshin

$$
\begin{aligned}
& \text { Ohayougozaimasu. } \\
& \text { Kyou } \\
& \text { kara, oku no koto wa } \\
& \text { souji } \\
& \text { mo Sentaku mo } \\
& \text { daidokoro } \\
& \text { shigoto mo minna, } \\
& \text { watakushi ga itashimasu. } \\
& \text { 'Selamat pagi. Dari } \\
& \text { sekarang, saya akan } \\
& \text { melakukan semua } \\
& \text { pekerjaan rumah } \\
& \text { tangga } \\
& \text { seperti bersih-bersih, } \\
& \text { mencuci, pekerjaan } \\
& \text { dapur dan lain } \\
& \text { sebagainya'. } \\
& \text { (diam). }
\end{aligned}
$$$$
\text { Genemon }
$$

(O80/01.22-01.30)

Pada data (34) di atas terlihat tuturan Oshin mematuhi prinsip kesantunan yaitu maksim kederrmawanan. Hal itu dibuktikan dengan pernyataan Oshin kepada Genemon bahwa dirinya-lah yang akan melakukan bersih-bersih, mencuci dan pekerjaan dapur. Pernyataan Oshin itu merupakan bukti bahwa Oshin telah mengurangi keuntungan diri sendiri dan menambah kerugian diri sendiri. Sehingga tuturan Oshin dikatakan mematuhi 
maksim kedermawanan dan merupakan

(O102/06.28-

tuturan santun.

\section{Maksim Pujian}

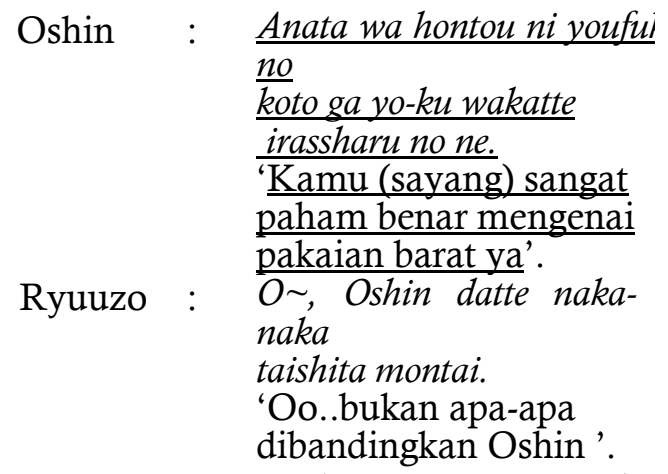

(O102/05.27-05.33)

Tuturan pada data (36) antara Oshin dan Ryuuzo telah mematuhi prinsip kesantunan yaitu maksim pujian. Pematuhan maksim pujian terlihat pada tuturan Oshin yang memberikan pujian kepada Ryuuzo dengan pernyataan Anata wa hontou ni youfuku no koto yoku wakatte irassharu none (kamu (sayang) sangat paham benar mengenai pakaian barat ya). Dikatakan memenuhi maksim pujian karena Oshin memaksimalkan rasa hormat kepada Ryuuzo (petutur) dengan cara memberikan pujian kepada petutur yang sangat paham mengenai pakaian barat.

\section{Maksim Kerendahan Hati}

$\begin{array}{ll}\text { Oshin } & : \frac{\text { Atama mo warui naa, }}{\text { atashi. }} \\ \text { Nakamoto } & \begin{array}{l}\text { 'Betapa bodohnya } \\ \text { saya'. }\end{array} \\ \begin{array}{l}\text { 'Sugi naremasuyo. } \\ \text { terbiasa lho'. }\end{array}\end{array}$

Pematuhan prinsip kesantunan, khususnya maksim kerendahan hati dapat dilihat pada tuturan Oshin data (38), ketika Oshin mengucapkan kalimat atama mo warui naa, atashi 'betapa bodohnya saya'. Tuturan yang diucapkan Oshin dikatakan mematuhi maksim kerendahan hati karena Oshin telah mengurangi pujian dan mengecam dirinya sendiri. Dengan mematuhi maksim kerendahan hati maka tuturan Oshin merupakan tururan santun.

\section{Maksim Kesepakatan}

$$
\begin{aligned}
& \text { Daigoro : Oshin-san. } \\
& \text { 'Saudari Oshin'. } \\
& \text { Oshin : } \quad \text { Hai }, \\
& \text { Daigoro : Anata kosakunin no }
\end{aligned}
$$

(O82/01.27-01.33)

Tuturan Oshin pada data (40) di atas merupakan tuturan yang mematuhi maksim kesepakatan. Hal itu dibuktikan dengan pernyataan Oshin yang mengucapkan hai untuk mengiyakan pertanyaan Daigoro tentang jati diri dan asal usul Oshin. Dikatakan mematuhi maksim kesepakatan karena Oshin sebagai penutur berusaha memaksimalkan kecocokan dengan petutur yaitu Daigoro. Dengan terpatuhinya maksim 
kesepakatan maka komunikasi antara Oshin dan Daigoro dapat berlangsung dengan baik.

\section{Maksim Kesimpatian}

$$
\begin{aligned}
& \text { Oshin : Okayo-sama ni wa } \\
& \text { shiawase ni } \\
& \text { natte itadakitain desu. } \\
& \text { 'Aku hanya ingin } \\
& \text { melihat } \\
& \text { Kayo : } \quad \begin{array}{l}
\text { Saudari Kumanne. } \\
\text { 'Maaf ya' }
\end{array}
\end{aligned}
$$$$
\text { (O85/10.17-10.28) }
$$

Tuturan Oshin pada data (42) telah terjadi pematuhan prinsip kesantunan yaitu maksim kesimpatian. Hal itu dibuktikan dengan pernyataan Oshin yang mengharap saudari Kayo memperoleh kebahagiaan. Dikatakan memenuhi maksim kesimpatian karena pernyataan Oshin itu telah memaksimalkan sikap simpati kepada petutur. Dengan pematuhaan maksim kesimpatian maka tuturan Oshin merupakan tuturan santun.

\section{Skala Kesantunan dalam Tuturan Variasi Bahasa Wanita}

Dalam tuturan variasi bahasa wanita Tokoh Shin Tanokura dalam drama serial Oshin telah ditemukan tuturan dengan skala kesantunan 1) Untung petutur-langsung-tinggi, 2) Untung petutur-langsung-sedang, 3) Untung petutur-langsung-rendah, 4) Untung petutur-tidak langsung-sedang, 5) Untung petutur-tidak langsung-rendah, 6) Untung penutur petutur-langsung-rendah dan 7) Untung penutur petutur-tidak langsung-tinggi.

\section{Untung petutur-langsung-tinggi}

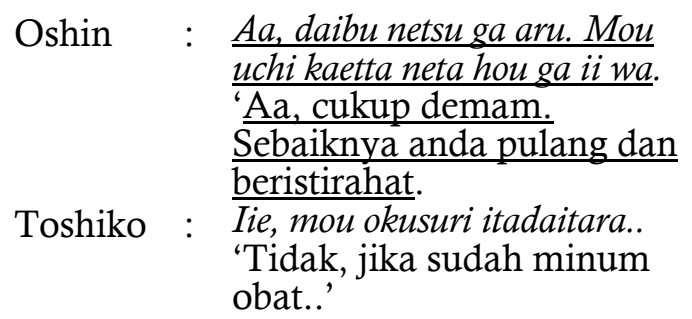

(O108/02.41-02.48)

Tuturan Oshin pada data (45), Oshin telah membuat keuntungan kepada petutur. Petutur, Toshiko merasa diuntungkan dengan disarankannya ia pulang karena mengalami demam. Oshin menggunakan kata sebaiknya yang menyatakan saran untuk menyuruh Toshiko pulang. Hal itu menunjukkan bahwa penutur secara langsung mengungkapkan maksud kepada petutur. Jika dilihat dari skala kemanasukaan, tuturan Oshin memberikan banyak pilihan dan keleluasaan kepada petutur. Sehingga petutur dapat secara leluasa menolak saran dari penutur dan masih dianggap santun. Hal itu dibuktikan dengan tuturan Toshiko yang berusaha menolak saran Oshin.

\section{Untung petutur-langsung-sedang}

(46) Oshin : Atashi no kao, yokatta, dondo mi ni kite choudai yo. "Jika anda ingin melihat saya, anda bisa datang kapan pun'.

Sabu : Hontou desuka. Benarkah?'.

(O100/09.54-09.58) 
Tuturan Oshin pada data (46), petutur merasa diuntungkan karena dapat menemui Oshin yang telah dianggap sebagai saudara sendiri sehingga tidak kesepian lagi. Penggunaan pola $\sim$ te choudai pada tuturan menunjukkan penutur secara langsung ingin mengungkapkan tujuannya kepada petutur. Penggunaan kalimat pengandaian pada tuturan memunculkan kemungkinan tuturan yang berkebalikan dari tuturan aslinya yaitu anata no kao, yokunakatta, mi ni konaidechoudai. Hal ini menunjukkan bahwa skala kemanasukaan dalam tuturan tersebut di atas bersifat sedang.

\section{Untung petutur-langsung-rendah}

$$
\begin{aligned}
& \text { Oshin : Anshin shite yasunde } \\
& \text { "Tenanglah dan silakan } \\
& \text { istirahat'. } \\
& \text { Toshiko : Sumimasen. } \\
& \text { 'Maaf'. } \\
& \text { (O108/03.03-03.06) }
\end{aligned}
$$

Tuturan Oshin pada data (47), Oshin mengucapkan tuturan Anshin shite yasunde choudai kepada Toshiko. Tuturan itu menunjukkan bahwa penutur secara langsung menyampaikan maksudnya yaitu mempersilakan petutur duduk. Sehigga dari tuturan itu petutur dirasa memperoleh keuntungan. Penggunaan pola $\sim$ te choudai menunjukkan bahwa penutur tidak memberikan petutur pilihan lain. Oleh karena itu, dapat dikatakan skala kemanasukaan pada tuturan itu rendah.

\section{Untung petutur-tidak langsung-sedang}

$$
\begin{array}{cl}
\text { Oshin }: & \frac{\text { Kawari ni atashi ga }}{\text { yattoku kara. Hidoku }} \\
& \frac{\text { demo nattara.. }}{\text { 'Sebagai gantinya saya }} \\
& \frac{\text { yang akan }}{\text { melakukannya. }} \\
\text { Tika menjadi semakin } & \text { parah..' } \\
\text { Toshik } & \begin{array}{l}
\text { Okusan ni, sonna.. } \\
\text { 'Nyonya, begitu...' } \\
\text { (O108/02.52-02.55) }
\end{array}
\end{array}
$$

Pada tuturan Oshin data (48) di atas, penutur menyampaikan tuturan berupa kalimat pernyataan yaitu 'sebagai gantinya saya yang akan melakukannya' untuk menyuruh Toshiko pulang dan beristirahat. Hal ini menunjukkan bahwa penutur mengungkapkan maksud dan tujuannya terhadap penutur secara tidak langsung. Penggunaan pola kalimat pengandaian $\sim$ tara pada tuturan memberikan dua pilihan yaitu jika menjadi semakin parah maka pulanglah dan jika tidak menjadi semakin parah maka tidak perlu pulang. Sehingga dikatakan skala kemanasukaan pada tuturan itu bersifat sedang. Jika dilihat dari skala untung rugi, petutur merasa diuntungkan karena dapat pulang dan beristirahat di rumah. 


\section{Untung petutur-tidak langsung-rendah}

(49) Oshin

\begin{tabular}{|c|c|}
\hline \multirow[t]{2}{*}{ shin } & $\begin{array}{l}\text { Dou tokoro de? Kochira } \\
\text { so Dana-sama to issho ni } \\
\text { youi shite arimasu kara. } \\
\text { 'Mengapa anda duduk } \\
\text { di sana? Duduklah di }\end{array}$ \\
\hline & $\begin{array}{lll}\text { sini } & \text { bersama } & \text { tuan, } \\
\text { sava }\end{array}$ \\
\hline & $\begin{array}{l}\text { saya sudah } \\
\text { menyiapkan mejanya'. }\end{array}$ \\
\hline Genemon & $\begin{array}{l}\text { Iie, waza shiyounin des } \\
\text { 'Tidak, saya hanya } \\
\text { seorang pelayan'. }\end{array}$ \\
\hline
\end{tabular}

(O80/03.46-03.55)

Pada tuturan Oshin data (49) di atas, penutur menawarkan petutur untuk duduk bersama tuannya melalui sebuah kalimat interogatif. Hal ini menunjukkan bahwa penutur menyampaikan maksudnya secara tidak langsung kepada petutur. Dalam tuturan itu penutur tidak memberikan pilihan kepada petutur untuk menentukan pilihannya sendiri. Hal ini menunjukkan bahwa tuturan itu memiliki skala kemanasukaan rendah. Jika dilihat dari skala untung rugi, terlihat bahwa petutur merasa diuntungkan karena dapat duduk bersama tuannya dalam satu meja.

\section{Untung penutur petutur-langsung-rendah}

$$
\begin{aligned}
& \text { Oshin : } \frac{\text { Okayo-sama ni wa shiawase }}{n i} \\
& \frac{n \text { natte itadakitain desu. }}{\text { 'Aku hanya ingin melihat }} \\
& \text { Kayo : } \begin{array}{l}
\text { Saudari Kayo bahagia'. } \\
\text { 'Manne. }
\end{array} \\
& \text { 'Maaf ya'. }
\end{aligned}
$$

Tuturan Oshin pada data (50), Oshin mengucapkan keinginannya secara langsung agar saudari Kayo menjadi bahagia sehingga petutur tidak mempunyai pilihan lain.
Dengan kata lain, hal itu menunjukkan skala kemanasukaan pada tuturan itu bersifat rendah. Jika dilihat dari skala untung rugi, baik petutur maupun penutur merasa diuntungkan dengan adanya tuturan itu. Petutur merasa diuntungkan karena disuruh menjadi bahagia. Penutur juga memperoleh keuntngan jika petutur menjadi bahagia.

\section{Untung penutur petutur-tidak langsung- tinggi}

(51)

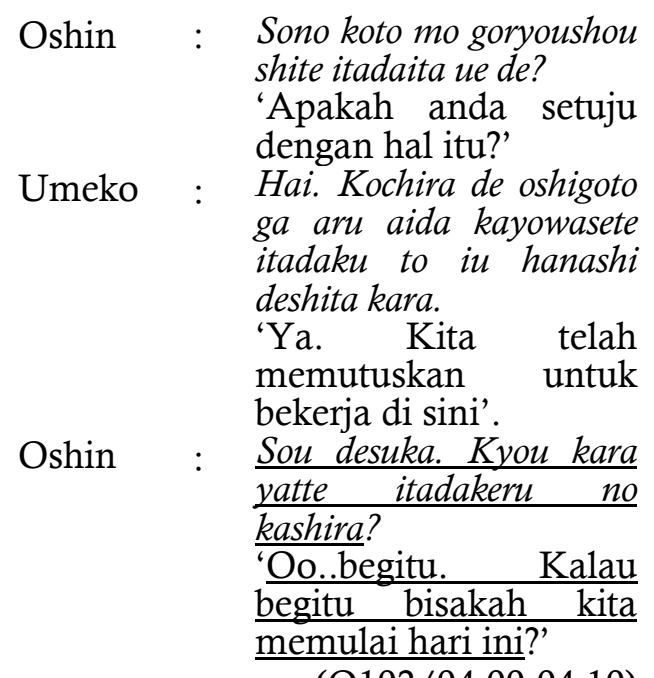

(O102/04.00-04.10)

Berdasarkan pembahasan dan analisis data pada bab IV, terlihat data tuturan variasi bahasa wanita sesuai dengan teori Kindaichi (1988) dan data terbanyak ada pada data tuturan variasi bahasa wanita yang menggunakan shuujoshi, yaitu sebanyak 12 data. Shuujoshi adalah joshi atau disebut partikel oleh pembelajar bahasa Jepang yang letaknya di akhir kalimat. Shuujoshi tidak dapat berdiri sendiri dan tidak memiliki makna. Walaupun shuujoshi tidak memiliki 
arti jika berdiri sendiri, namun shuujoshi memberikan tambahan makna yang kuat pada kalimat yang dilekatinya. Sebagai contoh, jika diperhatikan pada tuturan data (2) dengan kode O108/02.41-02.48, terlihat penggunaan shuujoshi wa memberikan makna tambahan yaitu memperlembut suara pada suatu tuturan. Jadi, tuturan yang dilekati shuujoshi wa menjadi tuturan yang memiliki kesan lembut. Kesan lembut yang ditimbulkan shuujoshi wa tersebut mencerminkan karakter seorang wanita. Sehingga bisa dikatakan penggunaan shuujoshi wa merupakan shuujoshi penanda tuturan variasi bahasa wanita dan tidak akan ditemukan pada tuturan yang diucapkan oleh seorang pria.

Data tuturan variasi bahasa wanita terbanyak selanjutnya adalah data tuturan variasi bahasa wanita yang menggunakan keigo 'bahasa santun'. Terdapat fakta menarik penggunaan bahasa santun dalam tuturan variasi bahasa wanita oleh Oshin (petutur), yaitu petutur mengucapkan tuturan dengan bahasa santun kepada setiap petutur tanpa memandang siapa dan apa statusnya. Petutur mengucapkan tuturan dengan bahasa santun kepada suami, teman suami, rekan bisnis, teman dekat, kerabat jauh, pegawai, pembantu bahkan orang yang tidak dikenal. Hal tersebut dilakukan petutur untuk menghormati petutur guna terjalin komunikasi dan hubungan tetap baik.
Sebaliknya, tuturan variasi bahasa wanita paling sedikit ada pada tuturan yang menggunakan wago, yaitu menggunakan verba tsuite iku sebanyak 1 data. Sesuai dengan penelitian Mineko Masamune (1998) dengan judul Nihongo ni okeru joseigo-danseigo dalam Jurnal Kitariku Daigaku volume 22 halaman 157 - 163 penggunaan verba tsuite $i k u$ ada pada data (22) dengan kode O96/11.50-11.55 merupakan penanda tuturan variasi bahasa wanita yang tidak dapat digantikan oleh verba zuikou suru yang merupakan kango.

Terdapat beberapa faktor yang mempengaruhi sedikitnya banyaknya data tuturan variasi bahasa wanita yang diperoleh dalam penelitian ini terutama faktor faktor sumber data. Penelitian ini menggunakan sumber data drama serial Oshin episode 80 sampai episode 111. Drama serial Oshin merupakan merupakan drama serial yang sangat popular di Jepang. Dalam drama serial Oshin, tokoh Shin Tanokura sering menggunakan tuturan variasi bahasa wanita dan bahasa santun. Jadi, drama serial Oshin merupakan sumber data yang sangat cocok untuk diteliti berkaitan dengan tuturan variasi bahasa wanita dan kesantunan berbahasa Jepang. Namun, karena drama serial Oshin menceritakan tentang kehidupan di masa pemerintahan meiji yang berkisar dari tahun 1860-an sampai 1900 menyebabkan bahasa yang digunakan dalam drama tersebut merupakan bahasa lama dan menggunakan 
dialek Yamagata. Sehingga hal tersebut menjadi kesulitan tersendiri bagi peneliti dalam proses menyimak dan transkripsi data.

Selanjutnya, jika dilihat dari segi kesantunan berbahasa, tuturan variasi bahasa wanita yang diucapkan oleh Oshin mematuhi keenam maksim prinsip kesantunan Leech (2011). Sehingga tuturan variasi bahasa wanita yang diucapkan oleh Oshin dikatakan sebagai tuturan santun. Selanjutnya, tuturan variasi bahasa wanita yang diucapkan oleh Oshin yang mematuhi prinsip kesantunan dilihat dari skala kesantunan untung rugi, data terbanyak ada pada tuturan yang memberikan keuntungan petutur. Oshin pada tuturan variasi bahasa wanita telah berusaha memaksimalkan keuntungan kepada petutur. Dengan memaksimalkan keutungan kepada petutur maka tuturan Oshin dikatakan sebagai tuturan santun.

\section{SIMPULAN DAN SARAN}

Berdasarkan pembahasan dan hasil diskusi pada bab sebelumnya maka dapat diambil simpulan sebagai berikut.

1. Tuturan variasi bahasa wanita tokoh Shin Tanokura dalam drama serial Oshin dapat dilihat melalui tiga tataran, yaitu: 1) Tataran goi meliputi penggunaan shuujoshi, kantanshi, ninshoudaimeishi, koshou, keigo dan wago, 2) Tataran tougo meliputi penggunaan iikiranai hyougen dan kurikaeshi hyougen, dan 3) Tataran danwa meliputi penggunaan youkyuu hyougen, aizuchi, dan aisatsu, kimari monku.

2. Ditemukan tuturan variasi bahasa wanita tokoh Shin Tanokura dalam drama serial Oshin yang mematuhi prinsip kesantunan berdasarkan teori Leech, yaitu: 1) Maksim kebijaksanaan, 2) Maksim kedermawanan, 3) Maksim pujian, 4) Maksim kerendahan hati, 5) Maksim kesepakatan dan 6) Maksim Kesimpatian.

3. Ditemukan skala kesantunan bahasa Jepang dalam tuturan variasi bahasa wanita tokoh Shin Tanokura dalam drama serial Oshin yaitu: 1) Skala untung rugi, 2) Skala ketidaklangsungan dan 3) Skala kemanasukaan. Dari ketiga skala kesantunan tersebut yang telah dipadukan dan diterapkan dalam tuturan variasi bahasa wanita ditemukan data dengan skala kesantunan sebagia berikut: untung petutur-langsung-tinggi, untung petuturlangsung-sedang, untung petuturlangsung-rendah, untung petutur-tidak langsung-sedang, untung petutur-tidak langsung-rendah, untung penutur petuturlangsung rendah dan untung penutur petutur-tidak langsung-tinggi.

\section{PUSTAKA RUJUKAN}

[1] Azuma, S. (2009). Shakai Gengogaku Nyuumon (Ikita Kotoba no Omoshirosa ni 
Tsuiru). Tokyo: Kenkyuusha Insatsu Kabushikigaisha.

[2] Chaer, A dan Leonie A. (2010). Sosiolinguistik Perkenalan Awal. Jakarta: Rineka Cipta.

[3] Chino, N. (2004). Diterjemahkan oleh Nasir Ramli: Partikel Penting Bahasa Jepang. Jakarta: Kesaint Blanc.

[4] Hirai, M. (1989). Nandemo Wakaru Shinkokugo Handobukku. Tokyo: Sanseido.

[5] Koizumi, T. (2013). Nyuumon: Goyouron Kenkyuu (Riron to Ouyou). Tokyo: Kenkyuusha.

[6] Kindaichi, H dkk. (1988). An Encyclopaedia of The Japanese Language. Tokyo: Taishukan Publishing Company.

[7] Leech, G. (2011). Prinsip-prinsip Pragmatik. Jakarta: Penerbit Universitas Indonesia.

[8] Mahsun. (2005). Metode Penelitian bahasa (Tahapan Strategi, Metode, dan Tekniknya). Jakarta: Raja Grafindo Persada.

[9] Masamune, M. (1998). "Nihongo ni Okeru Joseigo-Danseigo (On Women's Speech and Men's Speech in Japanese Language)". Kitariku Daigaku Kiyou, 22, 157 - 163.

[10] Miles, M B \& A Michael H. (2009). Analisis Data Kualitatif. Jakarta: Penerbit Universitas Indonesia.

[11] Mizutani, O dan Nobuko M. (1987). How to be polite in Japanese. Tokyo: Japan Times.

[12] Nakamura, J. (2000). "Shuujoshi ni Okeru Danseigo to Joseigo". Shinshuu Daigaku Ryungakusei Sentaa Kiyou, 1, 1 -11 .

[13] Nomura, M \& Seiji K. (1978). Nihongo Jiten. Tokyo: Tokyodou.

[14] Reiichi, H. (1990). Onna no Kotoba. Tokyo: Meiji Shoin.
[15] Setyorini, W. (2007). Tinjauan Penggunaan Shuujoshi sebagai Ragam Bahasa Jender dalam Kelas Bahasa Jepang di Perguruan Tinggi Jawa Timur. Tesis tidak diterbitkan. Surabaya: Pascasarjana Unesa.

[16] Shinmura, I. (1983). Koujien (Daisanban). Tokyo: Iwanamishoten.

[17] Subandi. (2008). Laporan Penelitian Fundamental Lanjutan: Persepsi Masyarakat Jepang Terhadap Ragam Bahasa Wanita Masyarakat Jepang. Surabaya: Lembaga Penelitian Unesa.

[18] Sudaryanto. (1993). Metode dan Teknik Analisis Bahasa: Pengantar Penelitian Wahana Kebudayaan secara Linguistis. Yogyakarta: Duta Wacana University Press.

[19] Sudjianto. (1996). Gramatika Bahasa Jepang Modern Seri A. Jakarta: Kesaint Blanc.

[20] Sudjianto. (2007). Bahasa Jepang dalam Konteks Sosial dan Kebudayaan. Jakarta: UPI Press.

[21] Sudjianto dan Dahidi, A. (2004). Pengantar Linguistik Bahasa Jepang. Jakarta: Kesaint Blanc.

[22] Sudjianto dan Dahidi, A. (2009). Pengantar Linguistik Bahasa Jepang. Jakarta: Kesaint Blanc.

[23] Sugiyono. (2012). Metodologi Penelitian Kuantitatife, Kualitatife, dan $R \& D$. Bandung: Alfabeta.

[24] Sutopo, HB. (2006). Metode Penelitian Kualitatif. Surakarta: UNS Press.

[25] Tamamura, F. (2001). Nihongogaku o manabu hito no tame ni. Tokyo: Sekaishishousha.

[26] Wijana, I D P. (1996). Dasar-dasar Pragmatik. Yogyakarta: Andi Offset.

[27] Wijana, I D P dan Rohmadi, A. (2006). Sosiolinguistik (Kajian Teori dan Analisis). Yogyakarta: Pustaka Pelajar. 